NEWS AND NOTES / NOUVELLES ET NOTES

Compiled by Gillian Griffith

Canadian Health Libraries Association / Association des bibliothèques de la santé du Canada

(CHLA / ABSC) response to budget cuts to Health Canada's Science Library Network

Clinical Queries filters in OVID's CINAHL

Google

The Health Education Assets Library (HEAL) collection expands

Hospital library standards

$2006 \mathrm{MeSH}$

National Network of Libraries for Health / Réseau national des bibliothèques pour la santé

Task Force update

National Library of Medicine (NLM) Technical Bulletin: new feature

Open Access report

PubMed news

CHLA / ABSC Annual Conference 2006 - Pearls of Wisdom

Living the Future 6: WOW - Where Next?

Medical Library Association (MLA) Annual Conference 2006 - Transformations A-Z

Special Libraries Association (SLA) 2006 Annual Meeting - Where Tradition and

Transformation Converge

$\underline{\text { Virtual Reference Desk (VRD) Conference }}$

World Library and Information Congress (WLIC) - 72nd IFLA General Conference and Council

FIS Professional Learning Centre - Influencing Decision Making: Strategies for Getting 


\section{NEWS AND NOTES / NOUVELLES ET NOTES}

\section{Canadian Health Libraries Association / Association des bibliothèques de la santé du Canada (CHLA / ABSC) response to budget cuts to Health Canada's Science Library Network}

View the response at http://www.chla-absc.ca/news/20060117HealthCanadaCuts.html.

\section{Clinical Queries filters in OVID's CINAHL}

OVID's CINAHL now has Clinical Queries filters that restrict retrieval to clinically sound studies. The filters have been based on the work of R. Brian Haynes et al., Health Information Research Unit, McMaster University. The categories are etiology, prognosis, qualitative, reviews, and treatment.

\section{Google}

Google Video has partnered with commercial publishers, including Aquarius Health Care Media, to offer a variety of health care-related videos covering sudden infant death syndrome (SIDS), diabetes and blindness, and other health issues. You will be required to download Google Video Player to view the videos, and the service is fee based. 


\section{The Health Education Assets Library (HEAL) collection expands}

HEAL is a digital library that provides freely accessible digital teaching resources of the highest quality to meet the needs of today's health sciences educators and learners. Recent additions include the Gallery of Hematology Images, the William F. Hoyt Neuro-Ophthalmology Collection, and the Medical Response to Weapons of Mass Destruction. Users may also try the site's federated search engine to search for the Multimedia Educational Resource for Learning and Online Teaching (MERLOT) repository.

\section{Hospital library standards}

The Task Force on Hospital Library Standards plans to post a draft of the revised standards for library and information services in Canadian health care facilities on the CHLA / ABSC Web site in early 2006. Comments on the proposed revisions are invited.

\section{$2006 \mathrm{MeSH}$}

What's New in MeSH (http://www.nlm.nih.gov/mesh/whatsnew.html) discusses the most significant new additions, deletions, and other changes to MeSH for 2006. Most notably, significant changes regarding bird flu (influenza A virus) have been made to MeSH for ease of use.

\section{National Network of Libraries for Health / Réseau national des bibliothèques pour la santé Task Force update}

A stakeholders meeting was held in June 2005. One of the outcomes of this meeting was the decision to move forward with the development of a business plan for the creation of a National Network of Libraries for Health. 


\section{National Library of Medicine (NLM) Technical Bulletin: new feature}

The NLM Technical Bulletin describes a new feature called Skill Kit. Skill Kit articles provide search hints, review system features, and cover data and indexing issues for NLM databases, expanding your search skills and knowledge. The latest feature, for example, is "Retrieving citations from a journal issue in PubMed" and includes step-by-step instructions with screen captures.

\section{Open Access report}

Sponsored by the Association of Learned and Professional Society Publishers (ALPSP), Highwire Press, and the American Association for the Advancement of Science (AAAS), with additional data from the Association of American Medical Colleges, the study's objective is to determine the impact of Open Access on scholarly journals' financial and nonfinancial factors, and to establish a substantial body of data about different forms of Open Access publishing and a baseline of comparison with traditional subscription publishing. The full report (The Facts about Open Access) may be downloaded at http://www.alpsp.org/publications/pub11.htm.

\section{PubMed news}

A printer-friendly format option has been added to the PubMed interface that creates a clean printout of your search results. 


\section{Meetings, conferences, and workshops}

\section{CHLA / ABSC Annual Conference 2006 - Pearls of Wisdom}

The 2006 CHLA / ABSC Annual Conference will take place in Vancouver, British Columbia, 12-16 May. To view the conference-at-a-glance and to find other conference-related information, visit http://www.chla-absc.ca/2006/. The preliminary program and online registration are slated to appear in late February. Contact information is available at chla.2006@ubc.ca.

\section{Living the Future 6: WOW - Where Next?}

If you are interested in a conference that focuses on future challenges facing libraries, check out Living the Future 6 at The University of Arizona (Tucson), 5-8 April 2006. The conference is cosponsored by the Association of Research Libraries, Office of Leadership and Management Services, and the Association of College and Research Libraries. John Perry Barlow, self-professed "free agent and peripheral visionary", is the closing keynote speaker. Details will soon be posted at http://www.library.arizona.edu/conferences/ltf/2006/index.html.

\section{Medical Library Association (MLA) Annual Conference 2006 - Transformations A-Z}

The annual MLA conference will take place 19-25 May in Phoenix, Arizona. For details, check the conference Web site at http://www.mlanet.org. 


\section{Special Libraries Association (SLA) 2006 Annual Meeting - Where Tradition and Transformation Converge}

SLA's Annual Conference will take place in Baltimore, Maryland, 11-14 June 2006. The keynote speakers are Gwen Ifill (The NewsHour with Jim Lehrer and Washington Week) and Walt Mossberg (The Wall Street Journal).

\section{Virtual Reference Desk (VRD) Conference}

Presentations, papers, bibliographies, handouts, and other resources from the 2005 annual VRD Conference (14-15 November) have been posted at WebJunction (http://www.webjunction.org/do/Navigation?category=11842).

\section{World Library and Information Congress (WLIC) - 72nd IFLA General Conference and Council}

"Libraries: Dynamic Engines for the Knowledge and Information Society" will take place 20-24 August 2006 in Seoul, Korea. The Health and Biosciences Libraries Section invites librarians, health informaticians, knowledge managers, educators, researchers, clinical staff, and others to submit proposals for papers, to be given in a 2-hour session as part of the program of the WLIC, which provide insight and experience of the role of new technologies in supporting access and delivery of health and health information. The theme is "What's new in technology for health information?" 


\section{Professional development}

\section{CHLA / ABSC 2006 Annual Conference - continuing education opportunities}

Courses that will be offered cover evidence-based practice, bioinformatics, and health statistics. Check the conference Web site (http://www.chla-absc.ca/2006/) for details and additional courses.

\section{FIS Professional Learning Centre - Influencing Decision Making: Strategies for Getting Results You Want}

At the end of the 2-day workshop scheduled for 2-3 March 2006, you will have developed a series of practical strategies for influencing others one-on-one, on a team basis, or when making a presentation to others.

If you would like a course, conference, or meeting included in an upcoming issue of JCHLA / JABSC, please send an e-mail to gillian.griffith@queensu.ca. 